\title{
The Impact of Economic Growth, Financial Development, and Trade Openness on Environmental Degradation in Egypt
}

\author{
Farman M. Ahmed', Dlawar M. Hadi ${ }^{2 *}$, Aso K. Ahmed ${ }^{3}$ \\ ${ }^{1}$ Department of Banking and Finance, College of Business Economy, Eastern Mediterranean University, Famagusta, North Cyprus, \\ ${ }^{2}$ Department of Accounting, College of Business, Komar University of Science and Technology, Sulaymania, Kurdistan Region, Iraq, \\ ${ }^{3}$ Department of Business Management, College of Business, University of Swez, Canal, Ismailia, Egypt
}

\author{
${ }^{*}$ Corresponding author: \\ Dlawar M. Hadi, \\ Department of Accounting, \\ College of Business, Komar \\ University of Science and \\ Technology, Sulaymania, \\ Kurdistan Region, Iraq. \\ E-mail: dlawar.mahdi@ \\ komar.edu.iq \\ Received: 18 December 2019 \\ Accepted: 25 February 2020 \\ Published: 30 June 2020 \\ DOI \\ 10.25156/pt.v10n1y2020.pp98-102
}

\section{A B S TR A C T}

This paper examines the effects of economic growth, financial development, and trade openness on the environment quality measured by $\mathrm{CO}_{2}$ emissions over the period of 1965-2014 in the case of Egypt. In this study, the series were stationary at their first difference form, and thus, a long-run model was adopted using the vector error correction model technique. The results confirm that the variables are cointegrated, indicating the long-run relationship between the variables. The empirical findings reveal a negative influence of economic growth and financial effect of the previous period of $\mathrm{CO}_{2}$ emissions, these effects are not significant in the short run. Any deviations from the long-run equilibrium return quickly, representing $59 \%$ speed of adjustment. The study proposes new policy insights into reduce $\mathrm{CO}_{2}$ emissions, especially in the long run.

Keywords: Economic growth; Financial development; Trade openness; $\mathrm{CO}_{2}$ emissions; Egypt

\section{INTRODUCTION}

$\mathrm{CO}_{2}$ emissions in Egypt have risen dramatically during the past decades [Figure 1]. As a result, environmental degradation has become a crucial phenomenon threatening global societies' safety. Recently, air pollution and environmental issues have become a serious concern in Egypt. In Cairo, in particular, the volume of pollution is more than 10- to 100-fold compared with the acceptable world standards. Air pollutants that are extremely high comprise particulate, hydrocarbons, and lead. These are all cancer-causing agents. The air in Egypt is extremely thick and gray, and there is a haze over Cairo. The sky is gray rather than blue, which is highly similar to the gray skies of Mexico City, London, and Beijing due to pollutants; clearly, the pollution has resulted in many respiratory diseases. The US Environmental Protection Agency has published risk data stating that, above the safe limit, the risk of developing serious respiratory diseases and cancer from inhaling particulates in the air (dust and soot, hydrocarbons, and heavy metal compounds) is 2 people for every 1000 (Hassanein, n.d.).

The Ministry of Environmental Affairs in Egypt, in cooperation with local and international development partners, develops environmental policies and programs that drive Egypt toward sustainable development. In the words of the ministry, "The human is the center of any development effort; humans deserve a better life, free of pollution" (Al-Wahaidy, 2017). This significant issue calls for studies to find the sources of air pollution and propose solutions guidelines to overcome it.

The aim of this study is investigating the effects of economic growth, financial development (FD), and trade openness (TO) on the environmental degradation measured by $\mathrm{CO}_{2}$ emissions in Egypt for the $1^{\text {st }}$ time. Indeed, this research is novel in that it provides the first empirical study regarding the abovementioned issue in the existing literature. From this perspective, the results will be interesting not only for scholars but also policymakers as well. Specifically, this study attempts to test the following hypothesis:

Hypothesis 1: Economic growth has no effect on the volume of $\mathrm{CO}_{2}$ emissions in Egypt.

Hypothesis 2: FD has no effect on the volume of $\mathrm{CO}_{2}$ emissions in Egypt.

Hypothesis 3: TO has no effect on the volume of $\mathrm{CO}_{2}$ emissions in Egypt.

The remainder of this paper is organized as follows: Section 2 gives a brief literature review. Section 3 presents the data and methodology used in the study. Section 4 


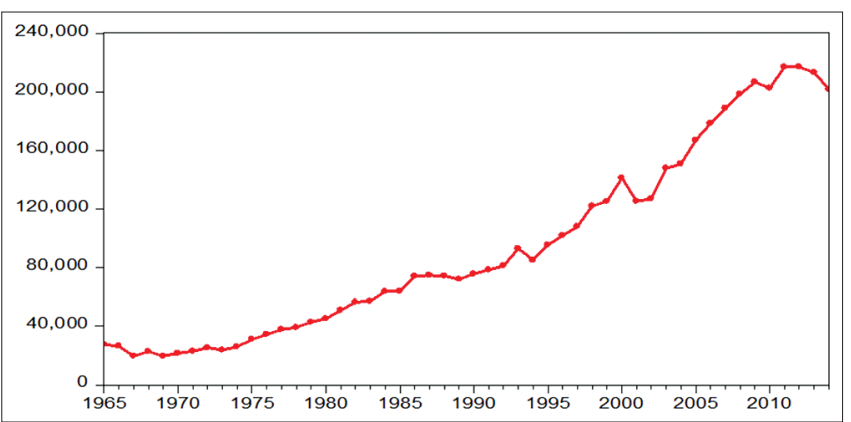

Figure 1: Egypt's $\mathrm{CO}_{2}$ emissions (kt) (Source: World Bank website, https://data.worldbank.org)

presents and discusses the results, and Section 5 concludes the study with some policy implications.

\section{REVIEW OF THE LITERATURE}

Economic growth is expected to increase $\mathrm{CO}_{2}$ emissions due to the vast energy consumption as the major engine for various industries and manufacturers (Shahbaz et al., 2013). In the literature, however, this relationship is linked to the environmental Kuznets curve (EKC) hypothesis (Panayotou, 1993). The EKC hypothesis claims that an inverted U-shaped relationship exists between various indicators of environmental pollution and economic activity. Under this hypothesis, environmental degradation increases during the initial stage of economic growth until a threshold level or turning point is reached in relation to income; after this point, the environmental degradation begins to decline. Using various methodologies, the unidirectional perspective and nexus between economic growth and environmental degradation in the framework of the EKC hypothesis, as well as for many countries and regions, have been extensively examined in the literature over the past decades (Dinda and Coondoo, 2006; Jha, 1996; Katircioglu and Celebi, 2018; List and Gallet, 1999; Managi and Jena, 2008; Roca, 2003; Shahbaz et al., 2013; Shafik, 1994; Tucker, 1995). Nevertheless, the results differ for distinct countries, confirming the argument that EKC is a country-specific phenomenon.

Many studies have used FD as a significant determinant of environmental degradation (Halicioglu, 2009; Jalil and Feridun, 2011; Tamazian and Rao, 2010). The most obvious reason for using FD in this study is that the existence of a well-developed financial sector attracts foreign direct investment, which, in turn, may stimulate economic growth and affect environmental quality (Frankel and Romer, 1999). In addition, FD results in the mobilization of financial resources for environment-related projects at reduced financing costs (Tamazian et al., 2009). Regarding the concern that environmental projects represent a public sector activity, Tamazian and Rao (2010) documented that a properly functioning financial sector will be especially helpful for all tiers of government to access finances for such projects. Moreover, FD may lead to technological innovations (King and Levine, 1993; Tadesse, 2005), and these technological changes can then contribute significantly to a reduction in emissions, particularly through the energy sector (Kumbaroglu et al., 2008). Finally, the announcements of rewards and acknowledgment of superior environmental performance have a positive effect on the capital market, which is a vital part of the financial system. Thus, $\mathrm{CO}_{2}$ emissions can be lessened by means of a solid financial system (Tamazian et al., 2009).

Regarding TO, it is argued that it provides an offer to each country to access international markets, which enhances the market share among countries (Shahbaz et al., 2012). This leads to competition between countries and increases the efficiency of using scarce resources; it also encourages importing cleaner technologies to lower $\mathrm{CO}_{2}$ emissions (Runge, 1994). Empirical evidence identifies TO as a determinant of $\mathrm{CO}_{2}$. Chen (2009) explored this issue in Chinese provinces and documented that the industrial sector's development is linked with an increase in $\mathrm{CO}_{2}$ emissions due to energy consumption. Nasir and Rehman (2011) used the augmented Dickey-Fuller (ADF) unit root test and the cointegration test supporting the EKC in Pakistan, and they reported a positive influence of $\mathrm{TO}$ on $\mathrm{CO}_{2}$ emissions; in contrast, Shahbaz et al. (2012) found that TO reduces $\mathrm{CO}_{2}$ emissions. Furthermore, Tiwari et al. (2013) reported that TO impedes environmental quality in the case of India.

It is worth mentioning that the existing literature provides several studies examining the effects of economic growth, $\mathrm{FD}$, and TO on the environmental degradation in countryand region-based contexts. However, no empirical study has attempted to examine the determinants of $\mathrm{CO}_{2}$ in Egypt, and the present study fills this gap.

\section{DATA AND METHODOLOGY}

The data from this study cover the period 1965-2014, and they were retrieved from the World Bank website (https:/ / data.worldbank.org/). The variables were $\mathrm{CO}_{2}$ emissions (kt), gross domestic product (GDP; current US\$), FD measures by domestic credit to the private sector (\% of GDP), and TO (TO; import + export; current US\$).

The present study investigates whether the GDP, FD, and TO have any influence on the $\mathrm{CO}_{2}$ increase in Egypt in the long run and short run. Therefore, the following model is proposed: 


$$
C O_{2 t}=\beta_{0}+\beta_{1} G D P_{t}+\beta_{2} F D_{t}+\beta_{3} T O_{t}+\varepsilon_{t}
$$

Where, $\beta_{0}$ is an intercept and $\beta_{1}, \beta_{2}$, and $\beta_{3}$ are the long-run and short-run coefficients. $\mathrm{CO}_{2}$ represents carbon dioxide emissions (kt), GDP is the GDP, FD is FD, TO is TO, and $\varepsilon_{t}$ is an error term. Equation (1) can be expressed in the logarithmic form; it is converted to capture long-term growth effects as follows (Katircioglu, 2009):

$$
\ln C \mathrm{O}_{2 t}=\beta_{0}+\beta_{1} \ln G D P_{t}+\beta_{2} \ln \mathrm{FD}+\beta_{3} \ln \mathrm{TO}+\varepsilon_{t}
$$

This study adopted the time series econometric techniques of estimation. The first step started with an investigation of the order of series using ADF (Dickey and Fuller, 1979) and Phillips and Perron's (1988; PP) method. Johansen cointegration was tested in the second step to investigate the cointegrating vectors. The error correction term (ECT) and short- and long-run coefficients were estimated in the third step. In the final stage, impulse response models plus variance decomposition (VD) ratios were estimated to further support this study's earlier results. These standard econometric approaches are not described in detail here because they are readily available and described in econometric theory and related textbooks.

\section{RESULTS AND DISCUSSION}

Before the empirical analyses, it was considered prudent to check the stationarity of the series. As shown in Table 1, the variables under consideration were found to be nonstationary in their level; this is because the null hypothesis of the unit root cannot be rejected, although the variables are stationary at their first difference.

Table 1: Unit root test

\begin{tabular}{lccccc}
\hline Variables & \multicolumn{2}{c}{ At level } & & \multicolumn{2}{c}{ At first difference } \\
\cline { 2 - 3 } \cline { 6 - 6 } & ADF & PP & & ADF & PP \\
\hline $\operatorname{LnCO} 2 \tau_{T}$ & -3.06 & -3.11 & & $-8.09^{*}$ & $-8.05^{*}$ \\
$\operatorname{LnGDP} \tau_{T}$ & -3.43 & -2.28 & & $-5.31^{*}$ & $-5.37^{*}$ \\
$\operatorname{LnFD} \tau_{T}$ & -0.81 & -1.04 & & $-7.39^{*}$ & $-7.36^{*}$ \\
$\operatorname{LnTO} \tau_{T}$ & -1.46 & -1.71 & & $-9^{*}$ & $-5.23^{*}$ \\
\hline
\end{tabular}

The null hypothesis states that the series has a unit root. An asterisk $\left({ }^{*}\right)$ symbolizes $1 \%$ significance level. $\tau_{\mathrm{T}}$ denotes the model with drift and trend. Optimum lag lengths are chosen based on the Schwartz criterion. ADF: Augmented Dickey-Fuller

\begin{tabular}{|c|c|c|c|c|c|c|}
\hline Lag & $\log L$ & LR & FPE & AIC & SC & $\mathrm{HQ}$ \\
\hline 0 & 133.9 & NA & $4.13 e-8$ & -5.651484 & -5.492472 & -5.591917 \\
\hline 1 & 339.3 & $366.0^{*}$ & $1.10 \mathrm{e}-1^{*}$ & $-13.88441^{*}$ & $-13.08935^{\star}$ & $-13.58658 *$ \\
\hline 2 & 352.8 & 21.70 & $1.25 e-1$ & -13.77527 & -12.34416 & -13.23916 \\
\hline 3 & 363.3 & 15.09 & $1.65 e-1$ & -13.53689 & -11.46973 & -12.76252 \\
\hline 4 & 378.5 & 19.18 & $1.86 e-1$ & -13.50 & -10.79969 & -12.49026 \\
\hline
\end{tabular}

Table 2: Lag selection
After importing the series into the vector autoregressive environment, to avoid biases, it is crucial to choose the appropriate lag. As shown in Table 2, all the criteria of lag selection propose lag length to be one lag. Therefore, the remaining analyses are based on one lag.

As pointed out above, the variables of this study are integrated as I (1). The present study adopts the Johansen approach for evaluating the presence of a long-run relationship between the variables [Table 3]. In fact, the trace test statistic detected one cointegrated equation among the variables under consideration. In line with the theoretical setting of this study, as anticipated, the results of the test identified that the variables are cointegrated in the study's models, implying that the sample of the study's variables is strongly cointegrated with the performance of $\mathrm{CO}_{2}$ in the long run.

The long-term and short-term coefficients are reported in Table 4. Clearly, the coefficients of all the explanatory variables are negative and highly statistically significant at $1 \%$ level of significance. The effect of the GDP on the

Table 3: Results of the Johansen cointegration test

\begin{tabular}{lccc}
\hline $\begin{array}{l}\text { Hypothesized no. } \\
\text { of CE(s) }\end{array}$ & $\begin{array}{c}\text { Trace } \\
\text { statistic }\end{array}$ & $\begin{array}{c}\text { 5\% critical } \\
\text { value }\end{array}$ & Prob. ** $^{*}$ \\
\hline None* & 49.03963 & 47.85613 & 0.0385 \\
At most 1 & 16.88377 & 29.79707 & 0.6486 \\
At most 2 & 5.116528 & 15.49471 & 0.7963 \\
At most 3 & 0.406186 & 3.841466 & 0.5239 \\
\hline
\end{tabular}

Table 4: Estimation of long-run, short-run, and error correction

\begin{tabular}{|c|c|c|c|}
\hline \multicolumn{4}{|c|}{ Panel (a). Long-run model } \\
\hline \multirow[t]{2}{*}{$\operatorname{lnGDP}(-1)$} & -0.298 & & \\
\hline & $(-4.09)^{*}$ & & \\
\hline \multirow[t]{2}{*}{$\operatorname{lnFD}(-1)$} & -0.323 & & \\
\hline & $(-6.13)^{*}$ & & \\
\hline \multirow[t]{2}{*}{$\operatorname{lnTO}(-1)$} & -0.243 & & \\
\hline & $(-3.77)$ * & & \\
\hline \multirow[t]{2}{*}{ C } & 1.255 & & \\
\hline & Panel (b). SI & ort-run model & \\
\hline Error correction & $\mathrm{D}\left(\mathrm{LNCO}_{2}\right)$ & & \\
\hline \multirow[t]{2}{*}{ CointEq1 } & -0.589844 & & \\
\hline & $(-5.01)^{\star}$ & & \\
\hline \multirow[t]{2}{*}{$\mathrm{D}(\operatorname{lnCO} 2(-1))$} & 0.203567 & R-squared & 0.479893 \\
\hline & $(-1.68)^{\star * \star}$ & Adj. R-squared & 0.417975 \\
\hline \multirow[t]{2}{*}{$\mathrm{D}(\ln G D P(-1))$} & -0.055897 & Sum sq. residuals & 0.035431 \\
\hline & $(-0.48)$ & S.E. equation & 0.029045 \\
\hline \multirow[t]{2}{*}{$\mathrm{D}(\operatorname{InFD}(-1))$} & 0.007685 & F-statistic & $7.750510^{*}$ \\
\hline & $(0.09)$ & Log likelihood & 104.9637 \\
\hline \multirow[t]{2}{*}{$\mathrm{D}(\operatorname{lnTO}(-1))$} & 0.110108 & Akaike AIC & -4.123487 \\
\hline & $(1.41)$ & Schwarz SC & -3.889587 \\
\hline \multirow[t]{2}{*}{ C } & 0.020002 & Mean dependent & 0.018351 \\
\hline & $(3.15)^{*}$ & S.D. dependent & 0.038071 \\
\hline
\end{tabular}
term coefficients

Values in () are $t$ statistics. Asterisks $\left({ }^{* * *, * *}\right.$, and $\left.{ }^{*}\right)$ symbolize significance $(10 \%, 5 \%$, and $1 \%$, respectively) 
$\mathrm{CO}_{2}$ emissions in Egypt is $-0.3 \%$, that is, with $1 \%$ increase in the GDP, $\mathrm{CO}_{2}$ emission decreases by $0.3 \%$ in the long run. This finding is consistent with the EKC hypothesis and the findings of Katircioglu and Taspinar (2017). Similarly, FD's effect on $\mathrm{CO}_{2}$ emissions is negative and statistically significant at $1 \%$ level of significance. The result exhibits that $0.323 \%$ reduction occurs in $\mathrm{CO}_{2}$ emissions if $\mathrm{FD}$ increases by $1 \%$. The negative sign of the coefficient of this variable may confirm that the financial sector in Egypt has achieved the level of maturity as this sector allocates resources to environmentally friendly projects and supports firms' use of advanced technology in production to enhance output levels. This result is in line with Tamazian and Rao (2010) who clarified the importance of financial and institutional developments for improving environmental quality. Parallel with the finding of Shahbaz et al. (2013), TO was found to be negatively associated with $\mathrm{CO}_{2}$ emissions and its coefficient, and the result was highly statistically significant. Precisely, it was observed that $1 \%$ increase in TO lowers $\mathrm{CO}_{2}$ emissions by $0.243 \%$. This finding can be justified in terms of competition among local producers, which encourages them to use advanced technology to minimize per unit cost; thus, they emit less energy pollutants during production.

The ECT and short-run coefficients were estimated in the next phase [Table 4]. The ECT was high, negative $(-58.98 \%)$, and statistically significant at $1 \%$ level, indicating that Egypt's $\mathrm{CO}_{2}$ emissions react to its long-run equilibrium by almost $59 \%$ speed of adjustment through the channels of GDP, FD, and TO. Regarding the shortrun effects of the variables, the explanatory variables showed no significant effect on $\mathrm{CO}_{2}$ emissions except in the previous period for $\mathrm{CO}_{2}$ itself. $\mathrm{CO}_{2}$ emissions in the previous period contribute to the degradation of the environment in the next period. It is observed that $1 \%$ increase in $\mathrm{CO}_{2}$ emissions is linked with $0.203 \%$ increase in $\mathrm{CO}_{2}$ in the future.

Finally, impulse response function (IRF) and VD tests were conducted to further enhance the earlier findings. The IRF test revealed that [Figure 2] the response of $\mathrm{CO}_{2}$ emissions to its own shocks was negative, while its response to GDP shocks was negligible and insignificant. However, $\mathrm{CO}_{2}$ emissions responded positively to FD in up to six periods and then became negative, while the responses to TO shocks were always positive.

Turning to VD - which is the substitute for IRF, as shown in Table 5 - the results revealed that, in the beginning periods, lower levels of forecast error variances could be demonstrated by the exogenous shocks to GDP, FD, and TO. However, the highest level varied among the $\mathrm{CO}_{2}$ emissions' determinants. For instance, the forecast error variance of $\mathrm{CO}_{2}$ emissions by a shock to the GDP

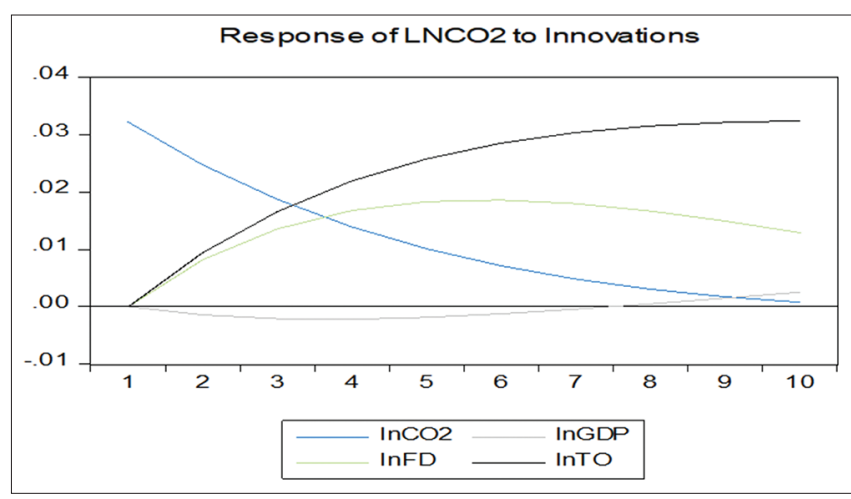

Figure 2: Impulse response function

Table 5: Variance decomposition of $\mathrm{LNCO}_{2}$

\begin{tabular}{lcccc} 
Period & LNCO $_{2}$ & LNGDP & LNFD & LNTO \\
\hline 1 & 100.0000 & 0.000000 & 0.000000 & 0.000000 \\
2 & 91.22832 & 0.112960 & 3.722218 & 4.936499 \\
3 & 76.22508 & 0.244498 & 9.610879 & 13.91954 \\
4 & 61.16492 & $\mathbf{0 . 3 1 1 5 3 8}$ & 14.90756 & 23.61598 \\
5 & 48.88987 & 0.311243 & 18.55309 & 32.24579 \\
6 & 39.69643 & 0.273134 & 20.60896 & 39.42148 \\
7 & 32.99156 & 0.227270 & 21.46514 & 45.31603 \\
8 & 28.09769 & 0.195902 & $\mathbf{2 1 . 4 9 9 6 5}$ & 50.20676 \\
9 & 24.47665 & 0.193893 & 21.00135 & 54.32810 \\
10 & 21.74422 & 0.230596 & 20.17687 & $\mathbf{5 7 . 8 4 8 3 1}$ \\
\hline
\end{tabular}

was $0.31 \%$ in period 4 , while these ratios were $21.5 \%$ and $57.84 \%$ for FD and TO in periods 8 and 10, respectively. Clearly, these variations in $\mathrm{CO}_{2}$ emissions can primarily be explained by TO followed by FD.

\section{CONCLUSION AND POLICY IMPLICATIONS}

The influences of economic growth, $\mathrm{FD}$, and $\mathrm{TO}$ on $\mathrm{CO}_{2}$ emissions have been demonstrated in the literature using various estimation techniques and in various countries and/or regions. Although air pollution has emerged as a real threat to Egyptians over many years, no previous empirical study has attempted to examine the determinants of $\mathrm{CO}_{2}$ emissions, the main source of air pollution, in Egypt. The present study examined the effects of economic growth, $\mathrm{FD}$, and $\mathrm{TO}$ on $\mathrm{CO}_{2}$ emissions in Egypt covering the time span of 1965-2014. As the series was found to be integrated at the first level, this study adopted a long-run time series model as the technique of estimation. The first result of this study's analyses revealed that the explanatory variables were cointegrated with $\mathrm{CO}_{2}$ emissions, indicating a long-run relationship among them. The long-run coefficients exhibited the inverse effects of economic growth, $\mathrm{FD}$, and TO on $\mathrm{CO}_{2}$ emissions at $0.3 \%, 0.32 \%$, and $0.24 \%$, respectively. In addition, any deviations of $\mathrm{CO}_{2}$ emissions from the long-run equilibrium with the independent variables returned quickly, with $59 \%$ speed of 
adjustment. However, the explanatory variables showed no significant effect on $\mathrm{CO}_{2}$ emissions except for $\mathrm{CO}_{2}$ itself in the previous period. $\mathrm{CO}_{2}$ emissions in the previous period contributed to the degradation of the environment in the next period. It was observed that $1 \%$ increase in $\mathrm{CO}_{2}$ emissions was linked with $0.203 \%$ increase in $\mathrm{CO}_{2}$ in the future.

The findings imply that carbon emissions can be reduced at the cost of economic growth, FD, and TO. Considering the findings, Egyptian policymakers can establish strategic plans to reduce environmental degradation. Specifically, all these channels can be dedicated and oriented to lessen energy consumption and adopt clean energy usage, and the support of the financial sector can help firms developing new technologies that will generate lower $\mathrm{CO}_{2}$ emissions.

In the framework of this study, further studies using a qualitative approach and/or different quantitative and empirical techniques are strongly recommended. The findings of this study are robust and can support Egyptian government decision makers to provide a cleaner society and reduce air pollution.

\section{REFERENCES}

Al-Wahaidy, F. 2017. Egypt's Approach to Protecting the Environment. Available from: https://www.egypttoday.com/Article/1/8836/ Egypt\%E2\%80\%99s-approach-to-protecting-the-environment. [Last accessed 2019 Nov 16].

Chen, S. 2009. Energy consumption, $\mathrm{CO}_{2}$ emission and sustainable development in Chinese industry. Econ. Res. J. 4(1): 1-5.

Dickey, D. A. and W. A. Fuller. 1979. Distribution of the estimators for autoregressive time series with a unit root. J. Am. Stat. Assoc. 74(366a): 427-431.

Dinda, S. and D. Coondoo. 2006. Income and emission: A panel databased cointegration analysis. Ecol. Econ. 57(2): 167-181.

Frankel, J. A. and D. H. Romer. 1999. Does trade cause growth? Am. Econ. Rev. 89(3): 379-399.

Halicioglu, F. 2009. An econometric study of $\mathrm{CO}_{2}$ emissions, energy consumption, income and foreign trade in Turkey. Energy Policy. 37(3): 1156-1164.

Hassanein, S. N. D. 2019. Air Pollution in Cairo-the Cost. Available from: http://www.arabworldbooks.com/articles1.html. [Last accessed on 2019 Nov 25].

Jalil, A. and M. Feridun. 2011. The impact of growth, energy and financial development on the environment in China: A cointegration analysis. Energy Econ. 33(2): 284-291.

Jha, S. K. 1996. The Kuznets curve: A reassessment. World Dev. 24(4): 773-780.

Katircioglu, S. and A. Celebi. 2018. Testing the role of external debt in environmental degradation: Empirical evidence from Turkey. Environ. Sci. Pollut. Res. 25(9): 8843-8852.

Katircioglu, S. T. 2009. Revisiting the tourism-led-growth hypothesis for Turkey using the bounds test and Johansen approach for cointegration. Tour. Manage. 30(1): 17-20.

Katircioglu, S. T. and N. Taşpinar. 2017. Testing the moderating role of financial development in an environmental Kuznets curve: Empirical evidence from Turkey. Renew. Sustain. Energy Rev. 68: $572-586$.

King, R. G. and R. Levine. 1993. Finance and growth: Schumpeter might be right. Q. J. Econ. 108(3): 717-737.

Kumbaroglu, G., N. Karali and Y. Arıkan. 2008. $\mathrm{CO}_{2}$, GDP and RET: An aggregate economic equilibrium analysis for Turkey. Energy Policy. 36(7): 2694-2708.

List, J. A. and C. A. Gallet. 1999. The environmental Kuznets curve: Does one size fit all? Ecol. Econ. 31(3): 409-423.

Managi, S. and P. R. Jena. 2008. Environmental productivity and Kuznets curve in India. Ecol. Econ. 65(2): 432-440.

Nasir, M. and F. U. Rehman. 2011. Environmental Kuznets curve for carbon emissions in Pakistan: An empirical investigation. Energy Policy. 39(3): 1857-1864.

Panayotou, T. 1993. Empirical Tests and Policy Analysis of Environmental Degradation at Different Stages of Economic Development (No. 992927783402676). International Labour Organization, Geneva, Switzerland.

Phillips, P. C. and P. Perron. 1988. Testing for a unit root in time series regression. Biometrika. 75(2): 335-346.

Roca, J. 2003. Do individual preferences explain the environmental Kuznets curve? Ecol. Econ. 45(1): 3-10.

Runge, C. F. 1994. Free Trade, Protected Environment: Balancing Trade Liberalization with Environmental Interests. Council on Foreign Relations, United States.

Shafik, N. 1994. Economic Development and Environmental Quality: An Econometric Analysis. Oxford Econ. Papers. 46: 757-773.

Shahbaz, M., A. K. Tiwari and M. Nasir. 2013. The effects of financial development, economic growth, coal consumption and trade openness on $\mathrm{CO}_{2}$ emissions in South Africa. Energy Policy. 61: 1452-1459.

Shahbaz, M., H. H. Lean and M. S. Shabbir. 2012. Environmental Kuznets curve hypothesis in Pakistan: Cointegration and Granger causality. Renew. Sustain. Energy Rev. 16(5): 29472953.

Shahbaz, M., Q. M. A. Hye, A. K. Tiwari and N. C. Leitão. 2013. Economic growth, energy consumption, financial development, international trade and $\mathrm{CO}_{2}$ emissions in Indonesia. Renew. Sustain. Energy Rev. 25: 109-121.

Tadesse, S. 2005. Financial Development and Technology, Working Paper no. 749. William Davidson Institute, Michigan.

Tamazian, A. and B. B. Rao. 2010. Do economic, financial and institutional developments matter for environmental degradation? Evidence from transitional economies. Energy Econ. 32(1): 137-145.

Tamazian, A., J. P. Chousa and K. C. Vadlamannati. 2009. Does higher economic and financial development lead to environmental degradation: Evidence from BRIC countries? Energy Policy. 37(1): 246-253.

Tiwari, A. K., M. Shahbaz and Q. M. A. Hye. 2013. The environmental Kuznets curve and the role of coal consumption in India: Cointegration and causality analysis in an open economy. Renew. Sustain. Energy Rev. 18: 519-527.

Tucker, M. 1995. Carbon dioxide emissions and global GDP. Ecol. Econ. 15(3): 215-223. 